\title{
Duloxetine Enhances TRAIL-mediated Apoptosis via AMPK- mediated Inhibition of Autophagy Flux in Lung Cancer Cells
}

\author{
K.M.A. ZINNAH ${ }^{1,2}$ and SANG-YOUEL PARK ${ }^{1}$ \\ ${ }^{1}$ Biosafety Research Institute, College of Veterinary Medicine, \\ Jeonbuk National University, Iksan, Republic of Korea; \\ ${ }^{2}$ Faculty of Biotechnology and Genetic Engineering, Department of Animal and Fish Biotechnology, \\ Sylhet Agricultural University, Sylhet, Bangladesh
}

\begin{abstract}
Background/Aim: The antidepressant duloxetine is known as a serotonin-norepinephrine reuptake inhibitor, used for treating depression and anxiety. TRAIL selectively induces cell death in a variety of tumor cells by binding to its membrane death receptor (DR). The aim of the study was to examine whether duloxetine affects TRAIL-mediated apoptosis. Materials and Methods: Cell viability and apoptosis was measured by morphological image, crystal violet staining, MTT and LDH assay. Immunocytochemistry and western blotting techniques were applied to detect autophagy and apoptosis indicator proteins. TEM assay was used to determine the autophagy. Results: Duloxetine treatment considerably sensitizes human lung adenocarcinoma cells to TRAIL-mediated apoptosis by targeting TRAIL-DR5. Treatment with duloxetine inhibited $A M P K$ phosphorylation and resulted in increased p62 and microtubule-associated protein $1 A / 1 B$ light chain $3 B-I I$ levels, indicating inhibition of autophagy flux. Blockade of DR5 with DR5-specific small-interfering RNA negatively regulated the apoptotic effect. Conclusion: Clinical administration of TRAIL in combination with duloxetine may serve as a therapeutic approach for the treatment of TRAILresistant lung cancer cells.
\end{abstract}

Lung cancer is one of the leading causes of cancer-related deaths worldwide $(1,2)$. After diagnosis, only $17.4 \%$ of patients with lung cancer survive for longer than 5 years (3). Several studies and clinical trials are in progress to develop specific treatment regimens for lung cancer that currently

Correspondence to: College of Veterinary Medicine, Jeonbuk National University, Gobong ro, Iksan, Jeonbuk 54596, Republic of Korea. Tel: +82 638500966, Fax: +82 638500910, e-mail: sypark@chonbuk.ac.kr

Key Words: Duloxetine, TRAIL, death receptor-5, apoptosis, autophagy. include surgery, radiotherapy, and chemotherapeutic drugs and their combinations $(4,5)$. The combination strategy has served as an important modality for cancer treatment for several years. Specific combination strategies with potent chemotherapeutic drugs may exert potential benefits against cancers, such as non-small cell lung adenocarcinoma (NSCLC) (6-8).

Tumor necrosis factor related apoptosis inducing ligand (TRAIL) is a transmembrane cytokine that selectively kills proliferating cancer cells via binding to death receptors on their membranes while exerting negligible toxicity to normal cells (9-12). However, many cancer cells exhibit resistance to TRAIL via various mechanisms, including genetic or epigenetic alteration of TRAIL receptors, overexpression of decoy receptors, and down-regulation of DR4/DR5 expression. Furthermore, overexpression of certain antiapoptotic proteins, such as cellular FLICE-like inhibitory protein (c-FLIP) and B cell lymphoma 2 (Bcl-2) is known to impair TRAIL functions (13-16). The binding of TRAIL to death receptors may also activate the extrinsic apoptotic pathway and trigger apoptotic signaling (17). TRAIL binds to its receptors, DR4 and DR5, to form a death-inducing signaling complex (DISC), which associates with adaptor molecules Fas-associated protein with death domain (FADD) and caspase- 8 and induces the activation of caspase- 9 and, subsequently, caspase-3 to cause apoptotic cell death (18-21). Among several TRAIL-resistant cancer cell lines, A549 lung cancer cells exhibit resistance to the apoptotic effects of TRAIL (22). Interestingly, TRAIL resistance may be overcome through the use of efficient TRAIL-sensitizing pharmacological agents $(23,24)$.

Duloxetine is a well-known serotonin-norepinephrine reuptake inhibitor that is widely used for the treatment of depression and anxiety. Duloxetine is also frequently prescribed for the treatment of depression in patients with cancer (25). In addition, duloxetine may serve as a standard drug for the treatment of chemotherapy-induced peripheral neuropathy (CIPN), wherein it prevents the activation and nuclear 
translocation of nuclear factor kappa $\mathrm{B}(\mathrm{NF}-\mathrm{kB})$ through the inhibition of the activation of $\mathrm{p} 38$ phosphorylation. As a consequence, it reduces inflammation and inhibits nerve injury through the regulation of nerve growth factor (NGF) (26).

Autophagy is an intracellular catabolic mechanism that involves formation of an autophagosome containing cytosolic components and damaged organelles, and its subsequent fusion with a lysosome (27-30). Defective autophagy has been associated with various diseases, including cancer, neurodegeneration, aging, and liver diseases $(31,32)$. The procedure of autophagosome development is facilitated by the ubiquitin-like ATG12-autophagy protein (Atg)5-Atg16 complex and microtubule-associated proteins $1 \mathrm{~A} / 1 \mathrm{~B}$ light chain 3B (LC3)-II, an LC3-I-phospholipid conjugate that serves as an autophagy marker $(33,34)$. Sequestosome-1 (p62), a ubiquitin-binding protein and an autophagy marker, integrates into autophagosome by directly interacting with LC3 and is completely degraded upon autophagy. Inhibition of autophagy flux results in the prompt accumulation of cellular p62, owing to the suppression of lysosomal degradation (35). The inhibition of autophagy flux sensitizes cancer cells to usual radio and chemotherapy response (36, 37). Autophagy inhibition may be a suitable target for cancer treatment. Chloroquine (CQ), 3-methyladenine (3-MA), and small-interfering RNA (siRNA) against autophagy-related genes have been employed as autophagy inhibitors in autophagy studies. Chloroquine (CQ) prevents lysosome acidification and lysosomal merging with autophagosomes as well as the degradation of proteins, thereby inducing apoptosis $(38,39)$. The molecule 3 -methyladenine (3-MA) is a specific inhibitor for phosphoinositide 3-kinase (PI3K) and autophagy (40, 41). AMP-activated protein kinase (AMPK), a key energy-preserving intracellular enzyme, regulates energy balance and maintains cellular energy homeostasis (42-44).

Here, we explored the use of duloxetine as a TRAILsensitizing agent for targeting the TRAIL/DR5 apoptotic pathway in A549 cells. We also investigated the molecular mechanism underlying the anticancer effects of duloxetine in combination with TRAIL and specifically the role of autophagy and AMPK phosphorylation.

\section{Materials and Methods}

Cell culture. Cancer cells originating from lung (A549, HCC-15) tumors were acquired from the American Type Culture Collection (Global Bioresource Center, Manassas, VA, USA). Calu-3 cancer cells were obtained from the Korean Cancer Cell Bank (KCBL), Republic of Korea. Cells were cultured in Roswell Park Memorial Institute (RPMI)-1640 medium (Gibco BRL, Grand Island, NY, USA) supplemented with $10 \%(\mathrm{v} / \mathrm{v})$ fetal bovine serum and antibiotics (100 $\mu \mathrm{g} / \mathrm{ml}$ penicillin-streptomycin) at $37^{\circ} \mathrm{C}$ in a $5 \% \mathrm{CO}_{2}$ incubator.

Reagents. Duloxetine was purchased from Cayman chemical, USA, and chloroquine $(10 \mu \mathrm{M})$ and 3-MA $(5 \mathrm{mM})$ were obtained from Sigma-
Aldrich (St. Louis, MO, USA). TRAIL (100 ng/ml) was purchased from AbFrontier (Geumcheon-gu, Seoul, Republic of Korea).

Cell viability test. A549, HCC-15, and Calu-3 cells were plated in 12 -well plates at a density of $1.0 \times 10^{4}$ cells/well and incubated at $37^{\circ} \mathrm{C}$ for $24 \mathrm{~h}$. The cells were pretreated with $0,5,10$, and $20 \mu \mathrm{M}$ duloxetine for $18 \mathrm{~h}$, followed by incubation with recombinant TRAIL $(100 \mathrm{ng} / \mathrm{ml})$ for $2.3 \mathrm{~h}$. In addition, the cells were also pretreated with chloroquine $(10 \mu \mathrm{M})$ for $1 \mathrm{~h}$, followed by treatment with duloxetine. Cellular morphology was observed under an inverted microscope (Nikon, Japan) and cell viability was assessed with the crystal violet staining method. Cells were stained with a staining solution $(0.5 \%$ crystal violet in $30 \%$ ethanol and $3 \%$ formaldehyde) for 10-15 $\mathrm{min}$ at room temperature, washed 3-4 times with phosphate-buffered saline (PBS), and dried. Cell viability was measured by adding $50 \mu \mathrm{l}$ of $5 \mathrm{mg} / \mathrm{ml}$ methyl-thiazolyltetrazolium (MTT) to each well, followed by the incubation of the plate at $37^{\circ} \mathrm{C}$ for $2 \mathrm{~h}$. The wells were treated with $500 \mu$ ldimethyl sulfoxide after the removal of the medium, and the absorbance of each well was measured at $570 \mathrm{~nm}$ with a spectrophotometer (BioRad, Hercules, CA, USA).

Lactate dehydrogenase $(\mathrm{LDH})$ assay. Cytotoxicity was determined using an LDH cytotoxicity detection kit (Takara Bio, Inc., Tokyo, Japan) according to the manufacturer's protocol. LDH activity was assessed by measuring absorbance at $490 \mathrm{~nm}$ using a microplate reader (Spectra Max M2, Molecular Devices, Sunnyvale, CA, USA).

Western blot assay. Treated A549 cells were washed with cold PBS, and resuspended in a lysis buffer [25 mM HEPES (pH 7.4), 100 $\mathrm{mM}$ ethylenediaminetetraacetic acid (EDTA), $5 \mathrm{mM} \mathrm{MgCl}_{2}, 0.1$ $\mathrm{mM}$ dithiothreitol (DTT), and a protease inhibitor cocktail], and sonicated to prepare cell lysates. Proteins (20-35 $\mu \mathrm{g})$ present in the cell lysates were separated by electrophoresis on $10 \%-15 \%$ sodium dodecyl sulfate (SDS) gels and transferred onto nitrocellulose and/or polyvinylidene fluoride (PVDF) membranes. After incubation with the indicated concentrations of primary antibodies in a dilution buffer (1\% milk with PBS-Tween) and with the secondary antibody $(1: 5,000)$, the membranes were developed with enhanced chemiluminescence reagents. Primary antibodies $(1: 1,000)$ used for immunoblotting included LC3, p62 (Sigma-Aldrich, St. Louis, MO, USA), cleaved caspase-3, p-AMPK $\alpha$, (Cell Signaling Technology, Danvers, MA, USA), cleaved caspase-8 (BD Pharmingen/BD Biosciences, San Jose, CA, USA), DR5 $(1: 10,000)$, DR4 $(1: 1,000)$ (Abcam, Cambridge, MA, USA), and $\beta$-actin (Sigma-Aldrich). The bands were visualized with a Fusion-FX7 imaging system (Vilber Lourmat, Marne-la-Vallée, France).

Immunocytochemistry (ICC). Cells were cultured on glass coverslips, treated with duloxetine, chloroquine, and/or TRAIL, washed with PBS, and fixed with $4 \%$ paraformaldehyde in PBS at room temperature for $15 \mathrm{~min}$. Cells were washed twice with icecold PBS and incubated at room temperature for $10 \mathrm{~min}$ in PBS containing $0.25 \%$ Triton X-100 (PBST). After incubation, cells were washed thrice with PBS and blocked with $1 \%$ bovine serum albumin (BSA) in PBST for $30 \mathrm{~min}$. The cells were incubated with appropriate primary antibodies (anti-p62, and DR5 diluted with $1 \%$ BSA in PBST) in a humidified chamber at room temperature for 3 $\mathrm{h}$ or at $4^{\circ} \mathrm{C}$ overnight. After incubation, the antibody solution was decanted and the cells were washed thrice with PBS, followed by 
A

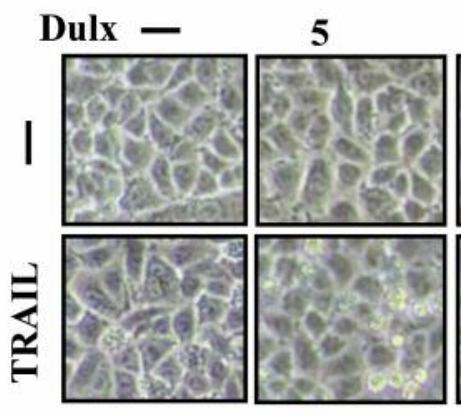

10

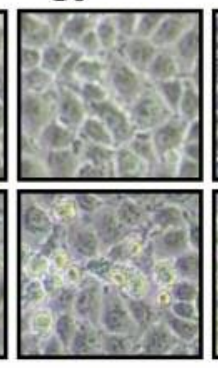

20

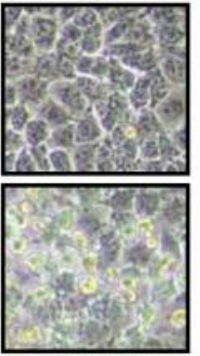

\section{B}

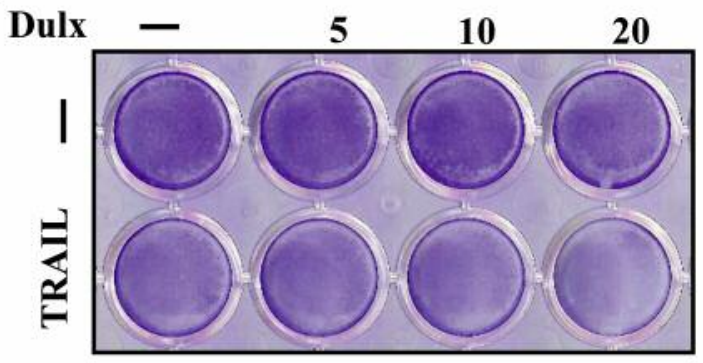

\section{C}

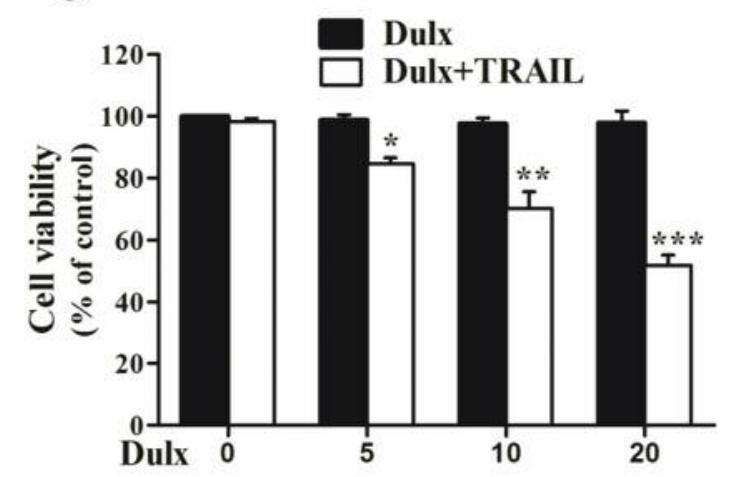

D

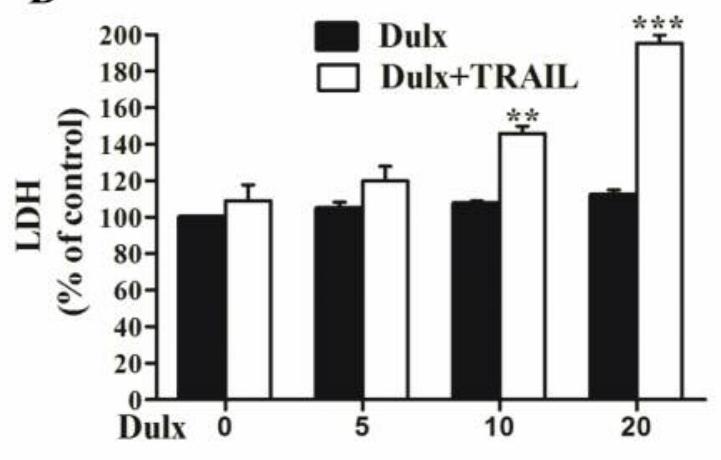

Figure 1. Effect of duloxetine on TRAIL-mediated apoptosis of A549 lung cancer cells. Cells were pretreated with 0, 5 , 10, and 20 $\mu$ M duloxetine for $18 \mathrm{~h}$ followed by additional treatment with $100 \mathrm{ng} / \mathrm{ml}$ of TRAIL for $2.3 \mathrm{~h}$. (A) Cells were photographed and changes in morphology were examined under a light microscope $(\times 100)$ in A549 cells; (B) Cell viability was determined with crystal violet staining; $(C)$ Bar graph presenting cell viability by MTT assay in A549 Cells; (D) Secretion of LDH during co-treatment measured in the supernatant of A549 cells. *p<0.05**p<0.01, ***p<0.001: significant differences between control and each treatment group, the results represent the means of at least 3 independent experiments. Dulx: Duloxetine; TRAIL: tumor necrosis factor (TNF)-related apoptosis-inducing ligand.

incubation with a secondary antibody (diluted with $1 \%$ BSA in PBST) in the dark for $2 \mathrm{~h}$ at room temperature. The solution was decanted and the cells were washed thrice with PBS (5 min per wash). Cells were incubated with 4',6-diamidino-2-phenylindole (DAPI) for $10 \mathrm{~min}$ and rinsed with PBS. Finally, the cells were mounted with a fluorescence mounting medium and visualized under a fluorescence microscope.

Transmission electron microscopy (TEM). Following fixation of the cells in 2\% glutaraldehyde (Electron Microscopy Sciences, Hatfield, PA, USA) and 2\% paraformaldehyde (Electron Microscopy Sciences) in $0.05 \mathrm{M}$ sodium cacodylate $(\mathrm{pH} 7.2$; Electron Microscopy Sciences) for $2 \mathrm{~h}$ at $4^{\circ} \mathrm{C}$, specimens were fixed in $1 \%$ osmium tetroxide (Electron Microscopy Sciences) for $1 \mathrm{~h}$ at $4^{\circ} \mathrm{C}$, dehydrated with increasing ethanol $(25,50,70,90$ and 100\%) for 5 min each and embedded in epoxy resin (Embed 812; Electron Microscopy Sciences) for $48 \mathrm{~h}$ at $60^{\circ} \mathrm{C}$ according to the manufacturers' instructions. Ultrathin sections $(60 \mathrm{~nm})$ were prepared using an LKB-III ultratome (Leica Microsystems GmbH, Wetzlar, Germany) and were stained with $0.5 \%$ uranyl acetate (Electron
Microscopy Sciences) for $20 \mathrm{~min}$ and $0.1 \%$ lead citrate (Electron Microscopy Sciences) for $7 \mathrm{~min}$ at room temperature. Images were recorded on a Hitachi H7650 electron microscope (Hitachi, Ltd., Tokyo, Japan; magnification, $\times 10,000)$ installed at the Center for University-Wide Research Facilities (CURF) at Chonbuk National University.

RNA interference. A549 cells were transfected with DR5 smallinterfering RNA (siRNA ID 104279; Ambion, Life Technologies Corporation) using Lipofectamine 2000 transfection reagent (Invitrogen; Thermo Fisher Scientific, Waltham, MA, USA) according to the manufacturer's instructions. After $24 \mathrm{~h}$, the knockdown efficiency at the protein level was determined by immunoblotting and cell viability assays. Scrambled siRNA (Invitrogen) was used as a negative control.

Ethical approval. Ethical approval for the project was granted by the institutional review board of the Chonbuk National University. Statistical analysis. All data are expressed as means \pm standard deviation (SD). Multiple comparisons were performed with one-way 
A

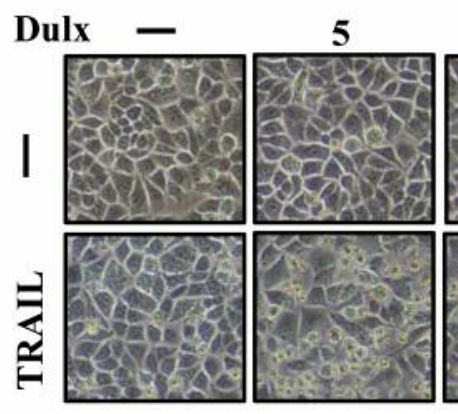

10

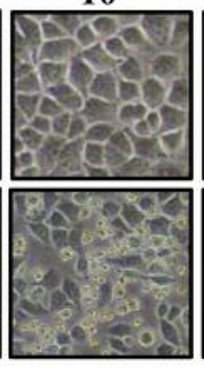

20

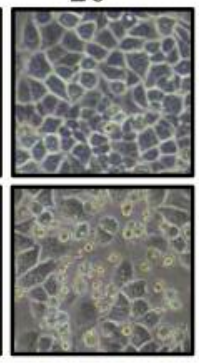

B

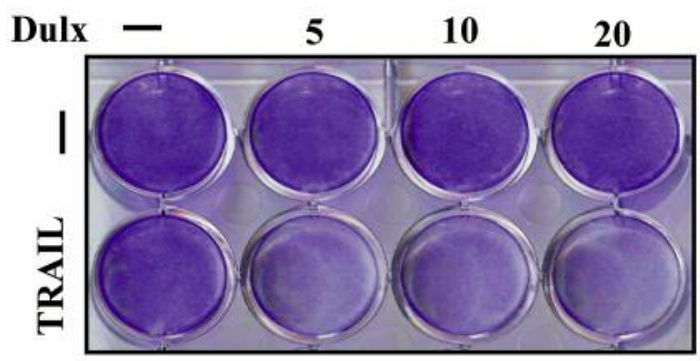

C

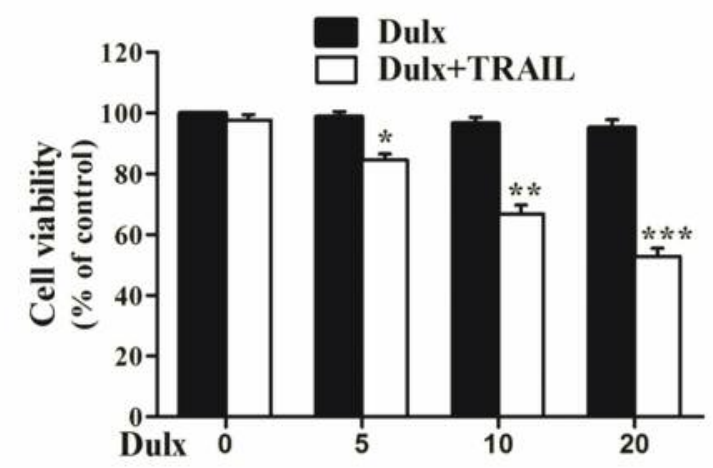

D

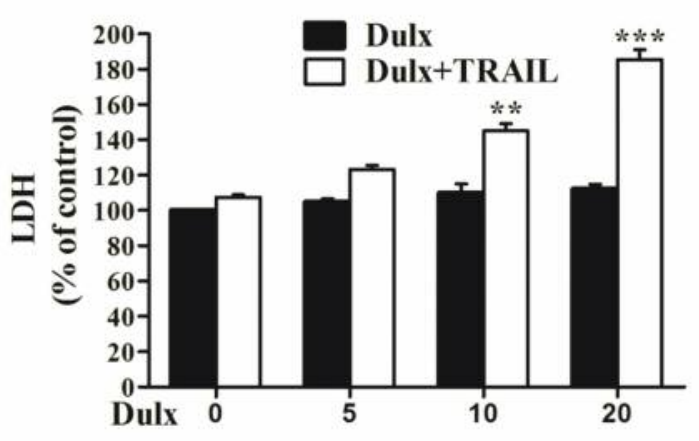

Figure 2. Effect of duloxetine on TRAIL-mediated apoptosis of HCC-15 lung cancer cells. Cells were pretreated with 0, 5 , 10 , and 20 $\mu$ M duloxetine for $18 \mathrm{~h}$ followed by additional treatment with $100 \mathrm{ng} / \mathrm{ml}$ of TRAIL for $2.3 \mathrm{~h}$. (A) Cells were photographed and changes in morphology were examined under a light microscope $(\times 100)$ in HCC-15 Cells; (B) Cell viability was determined with crystal violet staining; $(C)$ Bar graph presenting cell viability by MTT assay in HCC-15 Cells; (D) Secretion of LDH during co-treatment measured in the supernatant of HCC-15 cells. * $<<0.05 * * p<0.01$, $* * * p<0.001$ : significant differences between control and each treatment group, the results represent the means of at least 3 independent experiments.

analysis of variance (ANOVA) followed by Tukey-Kramer test. Statistical analyses were performed with GraphPad Prism software. A value of $p<0.05$ was considered to indicate a statistically significant difference.

\section{Results}

Effect of duloxetine on TRAIL-mediated apoptosis of lung cancer cells. The effect of duloxetine on the TRAIL-mediated apoptosis of A549, HCC-15, and Calu-3 lung cancer cell lines was evaluated following pretreatment with the indicated concentrations of duloxetine for $18 \mathrm{~h}$ and incubation with TRAIL for $2.3 \mathrm{~h}$. Cells were photographed and variations in their morphologies were examined under a light microscope. Treatment with duloxetine or TRAIL alone had minor effects on cell viability and failed to induce any morphological changes as compared with the control treatment (Figures 1, 2, and 3). Thus, A549, HCC-15, and Calu-3 cells were extremely resistant to TRAIL-mediated apoptosis. Cotreatment with TRAIL and varying concentrations of duloxetine induced an increase in the number of apoptotic cells (Figures 1A, B, 2A, B, and 3A, B). The results of the MTT assay showed a significant reduction in the viability and an increase in the percentage of A549, HCC-15, and Calu-3 cells undergoing apoptosis after co-treatment with duloxetine and TRAIL (Figures 1C, 2C, and 3C). The levels of $\mathrm{LDH}$ detected in all cell types after the combination treatment indicated that duloxetine significantly induced apoptosis in a dose-dependent manner and that duloxetine or TRAIL alone failed to have a similar effect (Figures 1D, 2D and 3D). These results suggested that duloxetine significantly sensitizes TRAIL-resistant lung adenocarcinoma A549, HCC-15, and Calu-3 cells to TRAIL-mediated apoptosis.

Duloxetine enhances DR5 expression to induce TRAILmediated apoptosis. To evaluate the molecular mechanism underlying apoptosis of A549 cells induced by the combination of duloxetine and TRAIL, we investigated the expression of death receptors involved in apoptosis (Figure 4). TRAIL could bind to the decoy receptors DcR 1 and 


\section{A}
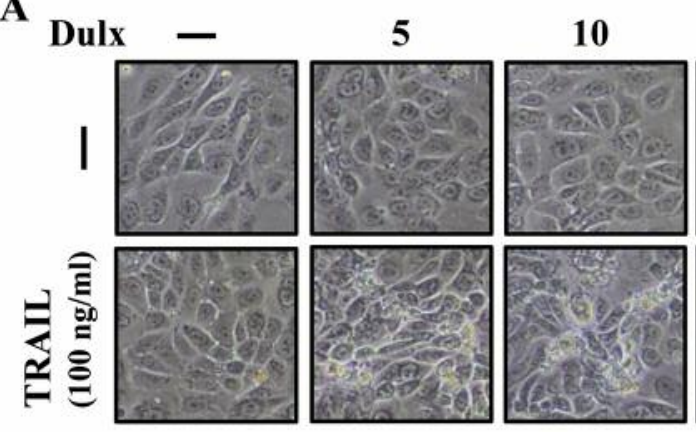

20
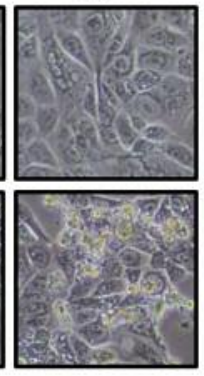

B

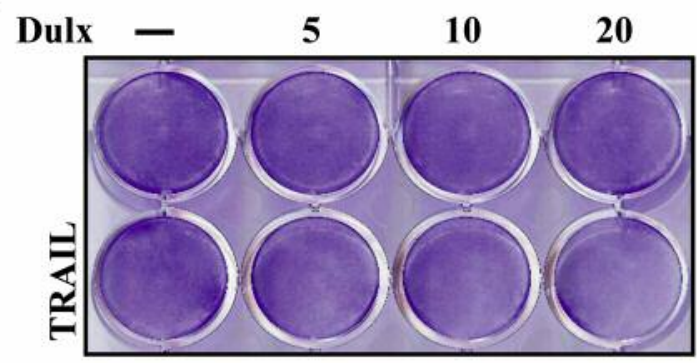

C

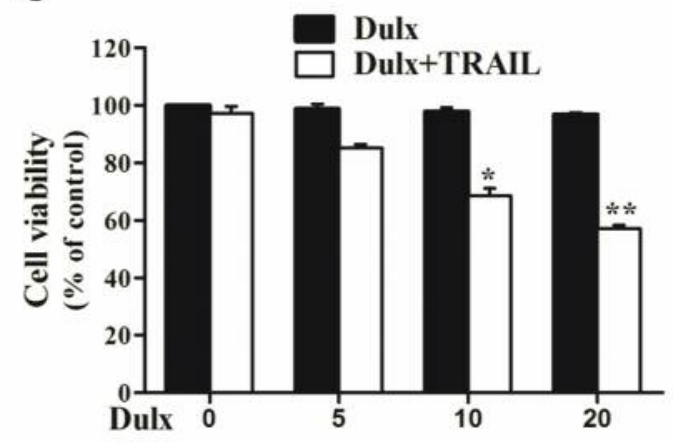

D

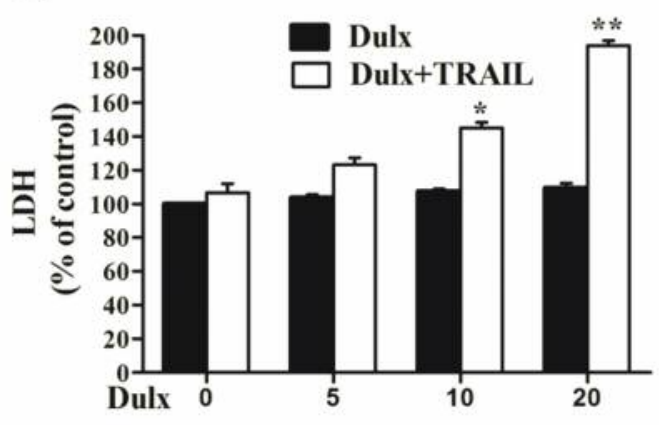

Figure 3. Effect of duloxetine on TRAIL-mediated apoptosis of Calu-3 lung cancer cells. Cells were pretreated with 0, 5, 10, and $20 \mu \mathrm{M}$ duloxetine for $18 \mathrm{~h}$ followed by additional treatment with $100 \mathrm{ng} / \mathrm{ml}$ of TRAIL for $2.3 \mathrm{~h}$. (A) Cells were photographed and changes in morphology were examined under a light microscope $(\times 100)$ in Calu-3 Cells; $(B)$ Cell viability was determined with crystal violet staining; $(C)$ Bar graph presenting cell viability by MTT assay in Calu-3 Cells; (D) Secretion of LDH during co-treatment measured in the supernatant of Calu-3 cells. ${ }^{*} p<0.01$, ${ }^{* *} p<0.001$ : significant differences between control and each treatment group, the results represent the means of at least 3 independent experiments.

DcR2 and to soluble osteoprotegerin and to DR4 and DR5 However, binding only to DR4 and DR5 allows transmission of apoptotic signals. A549 cells were treated with indicated concentrations of duloxetine for $18 \mathrm{~h}$ and cell lysates were subjected to western blot analysis to investigate the expression of DR4 and DR5. Duloxetine increased DR5 expression in a dose-dependent manner but expression of DR4 was not affected (Figure 4A). Apoptosis regulatory proteins cleaved caspase- 8 and cleaved caspase-3 were activated after treatment with duloxetine and TRAIL as compared to the single treatment with duloxetine or TRAIL (Figure 4B). Furthermore, ICC results also revealed significant activation of DR5 in duloxetine-treated cells as compared with non-treated cells (Figure 4C). These findings indicated that duloxetine upregulates DR5 to induce TRAIL-mediated apoptosis in lung adenocarcinoma cells.

Duloxetine mediated autophagy flux inhibition via suppression of AMPK phosphorylation. To investigate the role of duloxetine in autophagy flux, we assessed the expression levels of LC3-II and p62 by western blotting (Figure 5). The conversion of LC3I to LC3-II is a marker of complete autophagosomes, while p62 is a ubiquitinbinding protein involved in lysosome- or proteasomedependent degradation of proteins. Inhibition of autophagy flux results in the accumulation of cellular p62. LC3-II and p62 expression levels increased following duloxetine treatment, indicative of inhibition of autophagy flux (Figure 5A). ICC results also showed that duloxetine increased p62 levels in a dose-dependent manner (Figure 5B). Inhibition of AMPK phosphorylation resulted in cellular damage and prompted apoptosis through autophagy inhibition. Duloxetine repressed the phosphorylation of AMPK in a dose-dependent manner, resulting in suppression of autophagy flux (Figure 5C). Transmission electron microscopy confirmed inhibition of autophagy flux by the higher accumulation of autophagic vacuoles compared to control (Figure 5D). Taken together, these results indicated that inhibition of AMPK phosphorylation by duloxetine results in suppression of autophagy flux in lung cancer cells. 
A

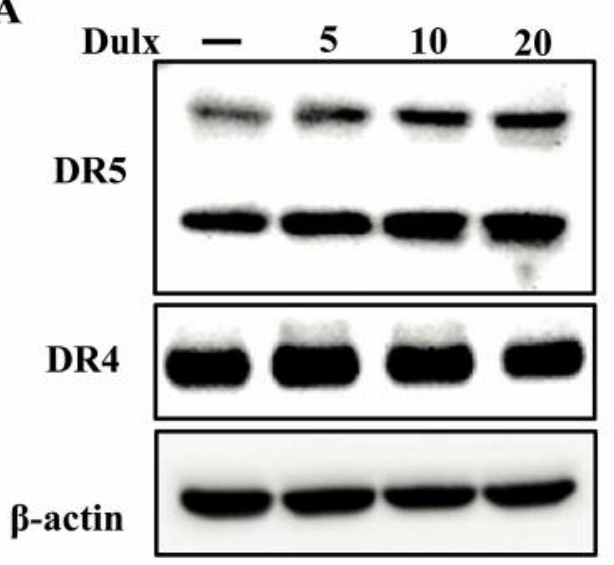

B

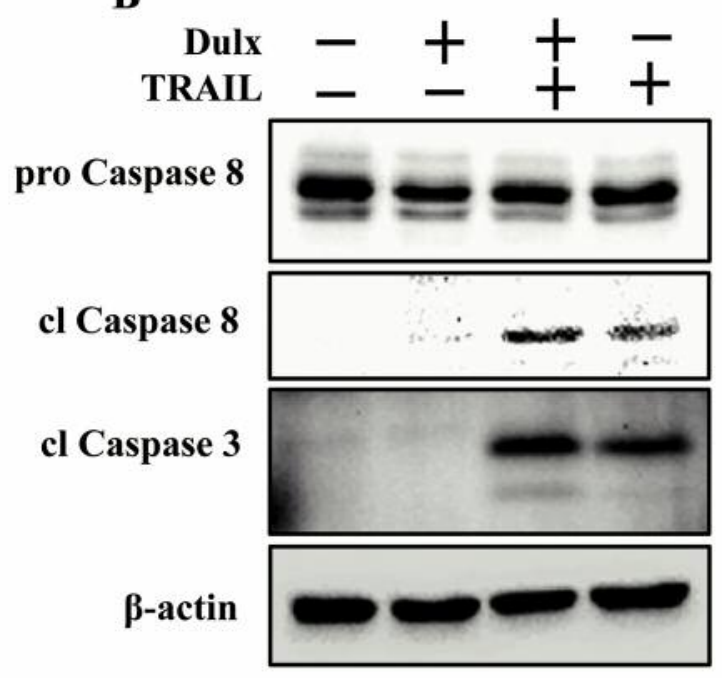

C

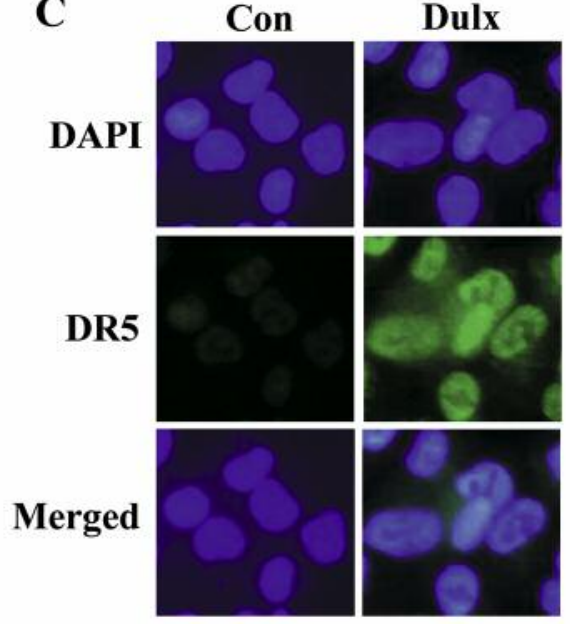

Figure 4. Duloxetine enhances DR5 expression to induce TRAILmediated apoptosis. A549 cells were pretreated with 0, 5, 10, and 20 $\mu M$ duloxetine for $18 \mathrm{~h}$. (A) Cells lysates were harvested and subjected to western blot to determine the activation of DR4 and DR5 in a dose-dependent manner; (B) Cells were treated with $20 \mu \mathrm{M}$ duloxetine for $18 \mathrm{~h}$ and then exposed to $100 \mathrm{ng} / \mathrm{ml}$ TRAIL for $2 \mathrm{~h}$. Immunoblotting was performed to detect cleaved caspase- 8 and cleaved caspase-3. $\beta$-actin was detected as a loading control; $(C)$ Immunocytochemistry results also showed the significant activation of DR5 in duloxetine- treated cells.

Duloxetine enhances TRAIL-mediated apoptosis by inhibiting autophagy flux. We used chloroquine to investigate the effect of duloxetine on the induction of TRAIL-mediated apoptosis of A549 lung adenocarcinoma cells. Chloroquine acts as an autophagy inhibitor by blocking the acidification of lysosomes. A549 cells were pretreated with chloroquine for 1 $\mathrm{h}$, then treated with indicated doses of duloxetine for $18 \mathrm{~h}$, and subsequently were incubated with TRAIL for an additional 2.3 h. Cells were visualized to investigate morphological changes using a light microscope and cell viability was analyzed using crystal violet staining and MTT assay (Figure 6). A549 cells treated with either TRAIL or duloxetine alone showed a slight increase in the cell death rate, but the combination treatment with TRAIL and chloroquine strongly increased the cell death rate. Cellular morphology analysis revealed an enhanced cell death after treatment with TRAIL and chloroquine as compared with that observed after treatment with duloxetine or TRAIL alone (Figure 6A and B). Incubation of chloroquinetreated A549 lung cancer cells with the combination of duloxetine and TRAIL reduced viability and significantly increased cell death (Figure 6C). LDH assay also showed that chloroquine, duloxetine both combined with TRAIL augmented apoptotic cell death (Figure 6D). These results indicated that duloxetine enhances TRAIL-mediated apoptosis through the inhibition of autophagy flux.

Autophagy flux inhibition results in DR5 up-regulation and enhances TRAIL-mediated apoptosis by duloxetine. We investigated the molecular mechanism underlying duloxetine-induced increase in TRAIL-mediated apoptotic pathway following inhibition of autophagy flux with autophagy inhibitors. Autophagy flux inhibition with autophagy inhibitor up-regulated DR5 expression, leading to an increase in apoptosis (Figure 7). We used two autophagy 


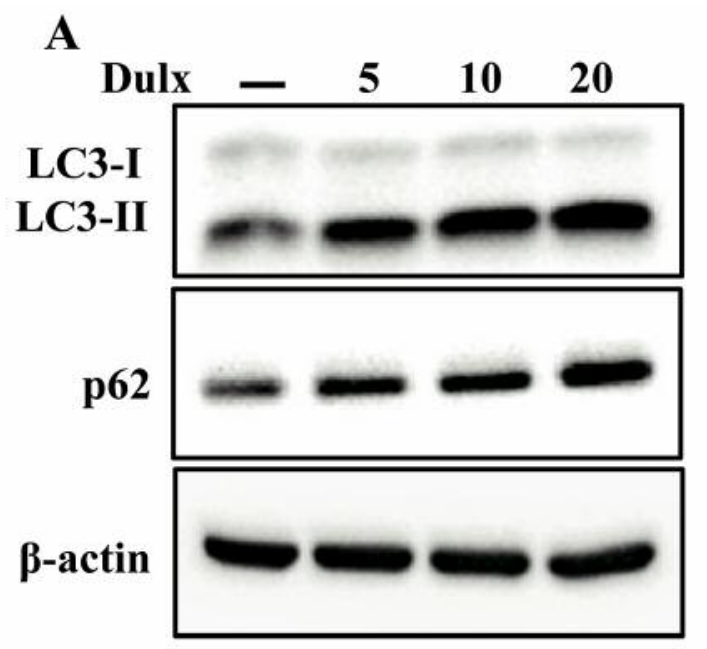

B
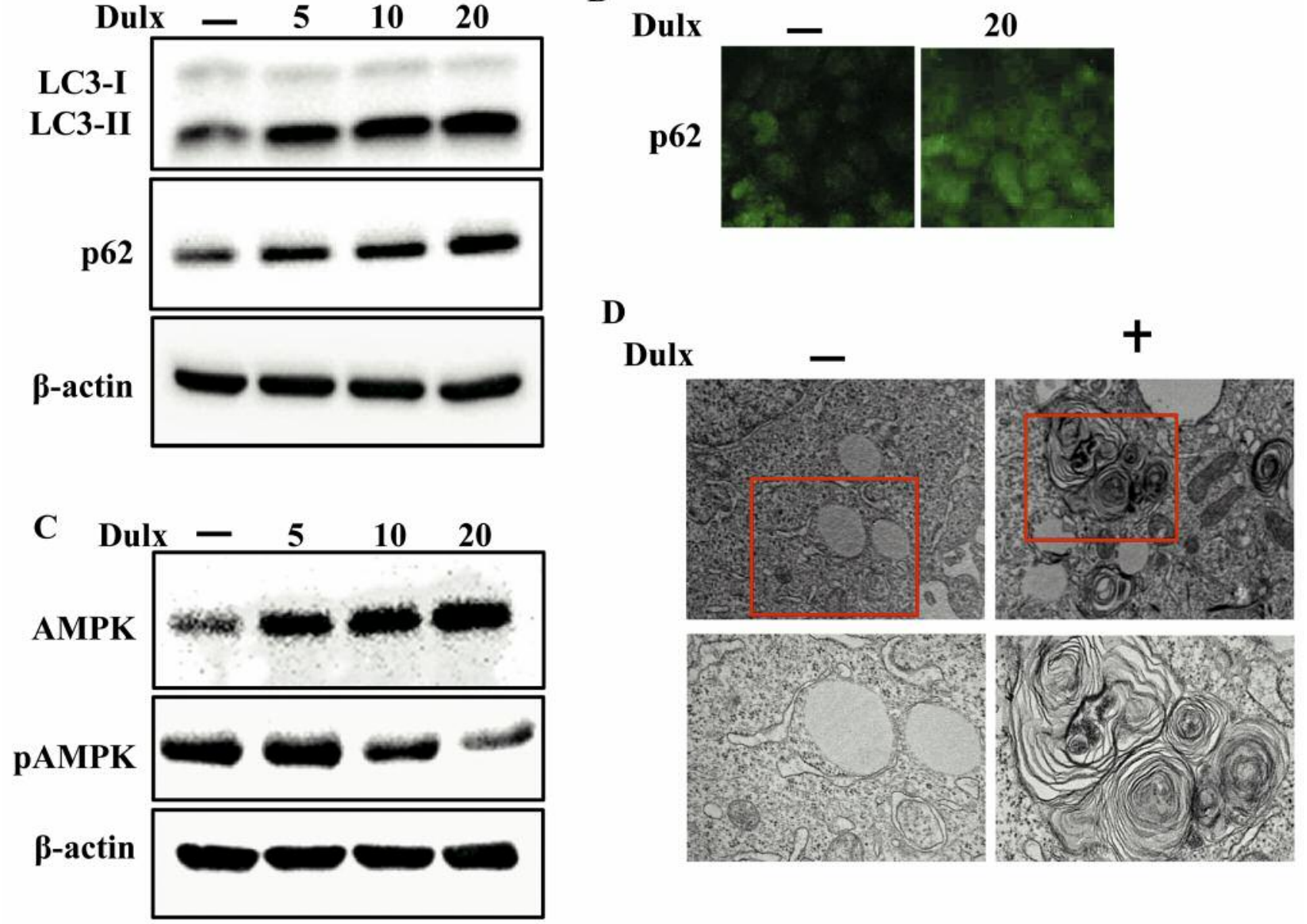

Figure 5. Duloxetine mediated autophagy flux inhibition via suppression of AMPK phosphorylation. Cells were treated with 0, 5, 10, and 20 $\mu M$

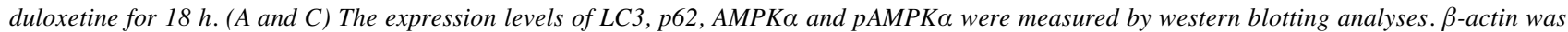
detected as loading control; (B) Immunocytochemistry results also showed the enhancement of p62 by duloxetine; (D) Transmission electron microscopy (TEM) results showed the accumulation of autophagosomes.

inhibitors; chloroquine and 3-MA. Lysates of cells pretreated with chloroquine $(10 \mu \mathrm{M})$ or 3 -MA $(5 \mathrm{mM})$ for $1 \mathrm{~h}$, and treated with the indicated concentrations of duloxetine for 18 $\mathrm{h}$ were analyzed by western blot. Duloxetine and chloroquine or 3-MA increased the levels of LC3-II. In addition, duloxetine alone in a dose-dependent manner, and chloroquine and 3-MA augmented p62 level. These results showed that duloxetine inhibits autophagy flux to induce apoptosis (Figure 7A). Furthermore, the combination of duloxetine with chloroquine and 3-MA up-regulated DR5 expression (Figure 7B). To evaluate the levels of cleaved caspase- 8 and cleaved caspase- 3 , lysates of cells pretreated with chloroquine for $1 \mathrm{~h}$, then treated with the indicated concentrations of duloxetine for $18 \mathrm{~h}$ and finally with TRAIL for an additional $2 \mathrm{~h}$ were examined by western blot. Inhibition of autophagy with chloroquine and TRAIL also activated caspase- 8 and caspase-3 (Figure 7C). These findings demonstrated that the inhibition of autophagy results in the up-regulation of DR5 expression and augments the duloxetine-induced TRAIL-mediated apoptosis.

Silencing of DR5 expression negatively regulates the duloxetine-induced TRAIL-mediated apoptosis. Inhibition of DR5 expression with DR5-specific siRNA meaningfully restored cellular viability after treatment with duloxetine and TRAIL. These data indicated that DR5 plays an important role in duloxetine-induced apoptosis mediated by TRAIL (Figure 8). Cells were transfected with DR5-specific siRNA or a negative control siRNA (NC) for $24 \mathrm{~h}$ and then treated with duloxetine for $18 \mathrm{~h}$, followed by incubation with TRAIL (100 $\mathrm{ng} / \mathrm{ml}$ ) for an additional $2.3 \mathrm{~h}$ to evaluate cell viability and 2 $\mathrm{h}$ for western blot analysis. We observed that cells transfected 

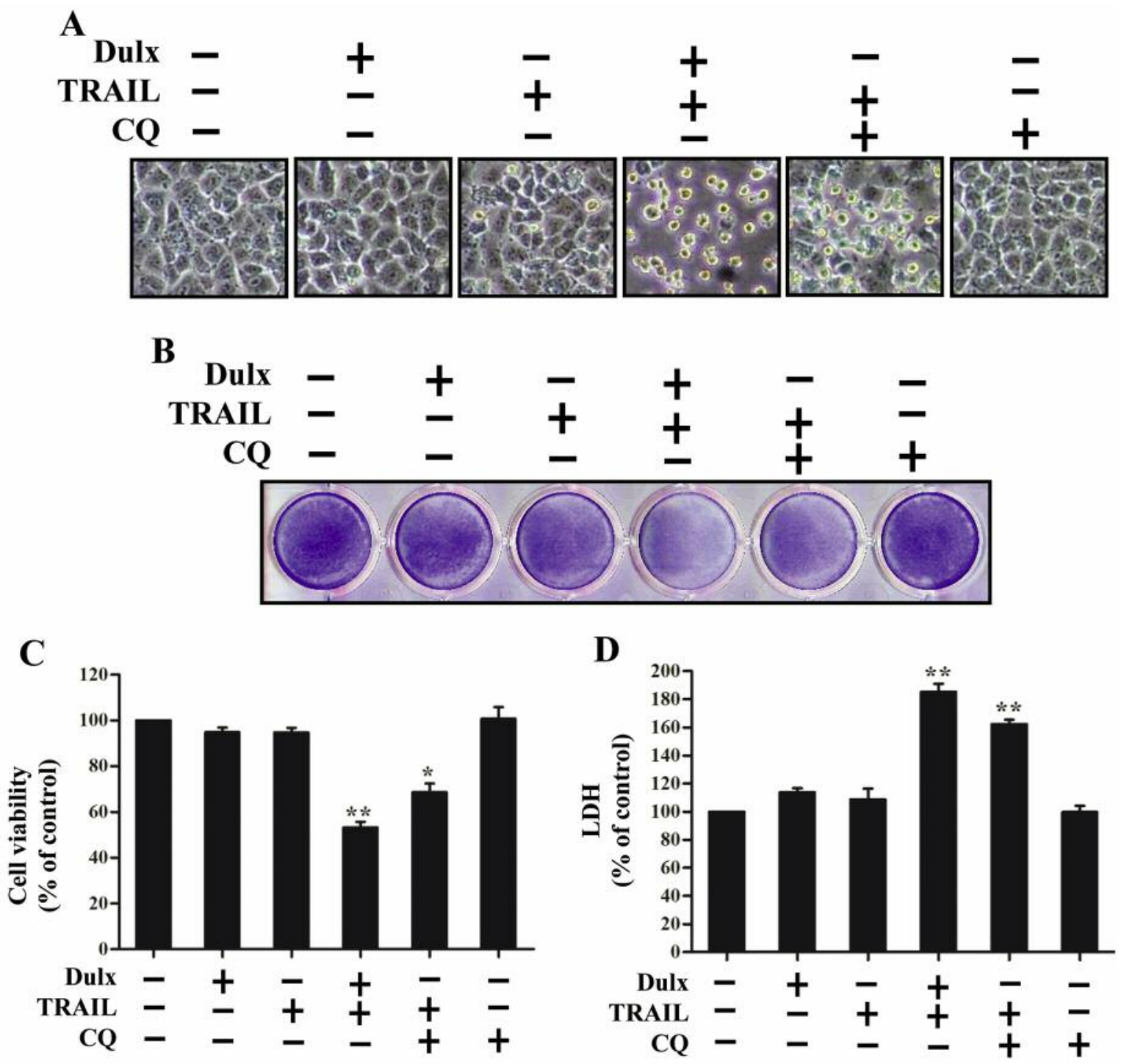

Figure 6. Duloxetine enhances TRAIL-mediated apoptosis by inhibiting autophagy flux. A549 cells were also pretreated with and/or chloroquine $(10 \mu \mathrm{M})$ for $1 \mathrm{~h}$ followed by treatment with $20 \mu \mathrm{M}$ duloxetine for $18 \mathrm{~h}$ finally exposed to $100 \mathrm{ng} / \mathrm{ml}$ TRAIL for $2.3 \mathrm{~h}$. (A) Cell morphology was photographed under light microscope (X100); (B) Cell viability was assessed by crystal violet staining; $(C)$. Bar diagram showed cell viability by MTT assay; (D) LDH assay showed apoptosis percentage. ${ }^{*} p<0.01,{ }^{*} p<0.001$ : significant differences between control and each treatment group, the results represent the means of at least 3 independent experiments. CQ: Chloroquine.

with DR5-specific siRNA showed a significant reduction in death induced by duloxetine and TRAIL co-treatment. Moreover, the viability of cells treated with the negative control siRNA was similar to that of cells co-treated with duloxetine and TRAIL (Figure 8A, B, and C). Western blot analysis of whole cell lysates showed that DR5 activity was blocked in cells transfected with DR5 siRNA as compared to the non-transfected samples (Figure 8D). Our findings confirmed that up-regulation of DR5 expression plays an important role in attenuating TRAIL resistance by duloxetine.
In summary, our findings showed that duloxetine-induced apoptosis is mediated by TRAIL via the AMPK-mediated inhibition of autophagy flux following the targeting of TRAIL-DR5 up-regulation.

\section{Discussion}

Depression is a very common psychological disorder in patients with cancer. Chronic stress decreases the antitumor immune response and favors tumor growth (45). Several 


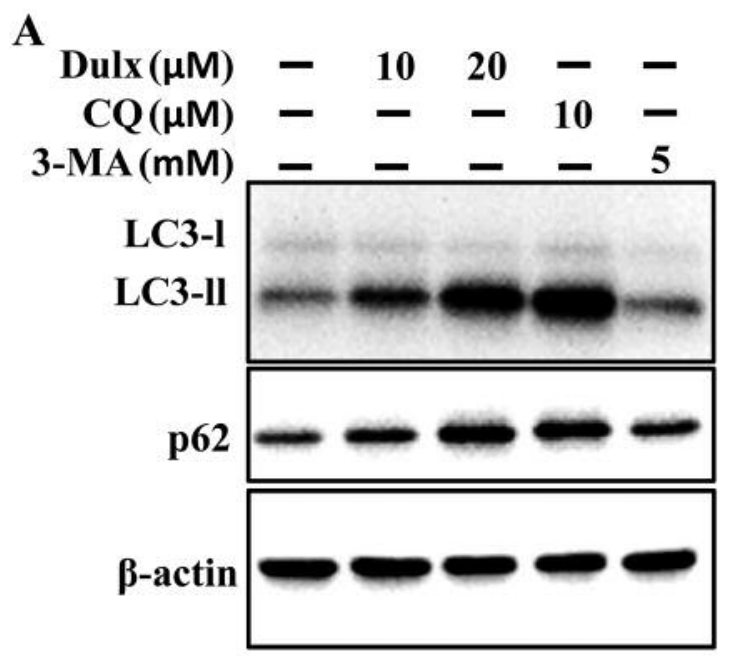

Figure 7. Autophagy flux inhibition results in DR5 up-regulation and enhancement in TRAIL-mediated apoptosis by duloxetine. Cells were pretreated with $10 \mu \mathrm{M}$ chloroquine, or 5mM 3-MA for 1 h followed by treatment with $20 \mu M$ duloxetine for $18 \mathrm{~h}$. (A) Autophagy marker LC3 and p62 were evaluated by western blot; (B). Death receptor 5 (DR5) was evaluated by immunoblotting; $(C)$ Cells were pretreated with $20 \mu \mathrm{M}$ duloxetine for $18 \mathrm{~h}$ and finally exposed to $100 \mathrm{ng} / \mathrm{ml}$ TRAIL for $2 \mathrm{~h}$. Cleaved Caspase- 8 and cleaved caspase- 3 were analyzed by immunoblotting. $\beta$-actin was detected as a loading control.3-MA: 3-Methyladenine.

studies using animal models have found that behavioral stress stimulates the rapid progression of ovarian (46), pancreatic (47), prostate (48), and breast (49) carcinomas and malignant melanomas (50). Duloxetine is commonly used to treat depression and is suggested as an adjuvant therapy for cancer pain management (51).

TRAIL is one of the most promising anticancer agents owing to its specificity, ability to initiate apoptosis in specific cell types, and non-toxicity to normal cells (52-56). Previous studies have confirmed that the repetitive administration of TRAIL may adequately inhibit tumor growth without affecting normal cells $(55,57)$. However, several cancers, including lung cancer, are resistant to the apoptotic effects of TRAIL (58). Surprisingly, TRAIL resistance could be overcome with the use of efficient TRAIL-sensitizing pharmacological agents in the form of combination therapy (19).

Our study demonstrated that small doses of duloxetine in combination with TRAIL effectively increase the number of

\section{B}
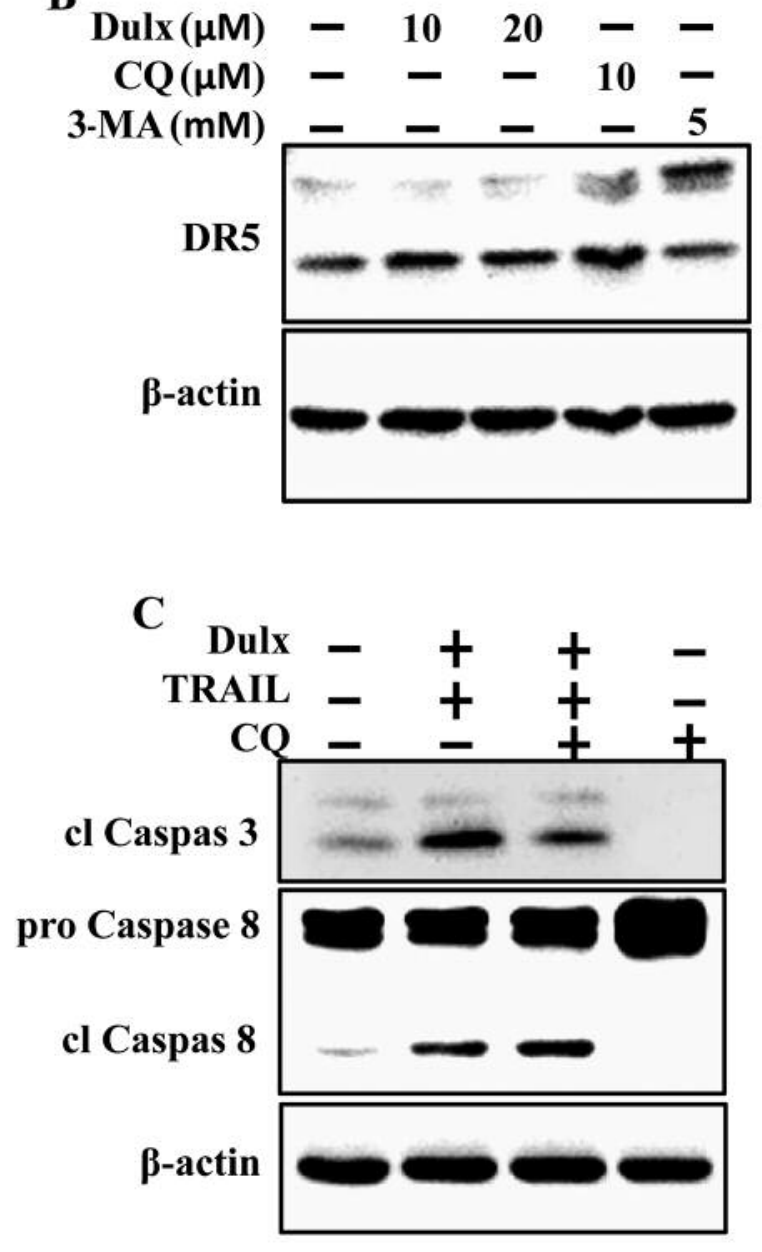

apoptotic cells as compared to the administration of either treatment alone. We investigated whether duloxetine attenuates TRAIL resistance of A549, HCC-15, and Calu-3 cells and activates the apoptotic caspase cascade in these cells and found that duloxetine up-regulated DR5 expression, leading to the apoptotic cell death in combination with TRAIL (Figures 1, 2, 3, and 4).

Autophagy is a natural, self-regulated mechanism responsible for cell death or survival through the elimination of cytoplasmic proteins and other macromolecules, clearance of damaged organelles, and degradation of dysfunctional or aggregated proteins $(59,60)$. Autophagy supports cells by mediating an immediate response necessary for the recycling of indispensable metabolites as well as to fuel bioenergetic machineries. Many studies suggest that the blockade of lysosomal degradation in response to the inhibition of autophagy machinery in starved cells may result in rapid apoptotic cell death through the activation of death receptors 

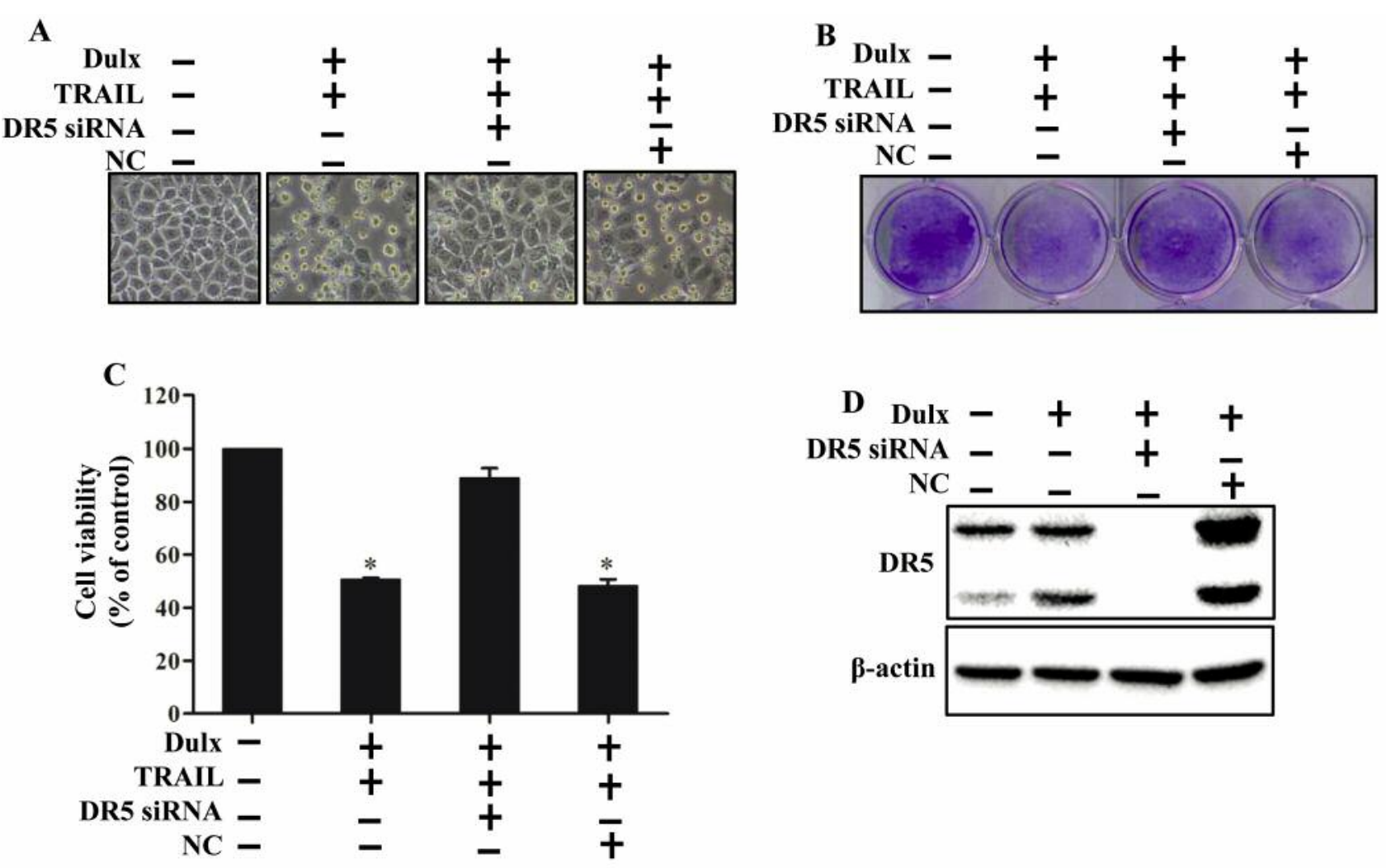

Figure 8. Silencing of DR5 expression negatively regulates duloxetine-induced TRAIL-mediated apoptosis. A549 cells were transfected with DR5 siRNA and NC siRNA (40 $\mathrm{nM}$ ) for $24 \mathrm{~h}$ then treated with $20 \mu \mathrm{M}$ duloxetine for $18 \mathrm{~h}$ with or without $100 \mathrm{ng} / \mathrm{ml}$ TRAIL for $2.3 \mathrm{~h}$ and $2 \mathrm{~h}$ for evaluating cell viability and performing immunoblotting; (A) Cells were photographed and changes in morphology were examined under a light microscope (×100); (B) Cell viability was determined with crystal violet staining; (C) Bar graph showing the cell viability percentages by MTT assay. * $p<0.001$ : significant differences between control and each treatment group; $(D)$ Cells lysates were harvested and subjected to western blot to determine the expression of DR5. $\beta$-actin was detected as a loading control.

and expression of apoptotic caspase cascades (36, 61-63). AMPK is a cellular energy sensor related to survival and proliferation of cells through the induction of cytoprotective autophagy via the direct inhibition of mTOR. Down-regulation of AMPK phosphorylation triggers cellular apoptosis via autophagy inhibition $(64,65)$. Our findings confirmed that duloxetine increased autophagosome formation, as evident from the increase in LC3-II expression, and triggered defective lysosomal degradation as indicated by the accumulation of p62, causing inhibition of autophagy flux (Figure 5). The combination treatment of TRAIL and duloxetine or CQ increased cell death as compared with single treatment regimens (Figure 6). We confirmed that the inhibition of autophagy with duloxetine and the specific autophagy inhibitors chloroquine and 3-MA resulted in the up-regulation of the expression of DR5 and enhanced TRAIL-mediated caspase-dependent death of lung cancer cells. Furthermore, duloxetine- and TRAIL-induced apoptosis in response to the inhibition of autophagy flux was confirmed after treatment with the autophagy inhibitor chloroquine (Figure 7) $(66,67)$. The blockade of DR5 expression with DR5-specific siRNA abrogated TRAIL-mediated apoptosis of cells (Figure 8).

Our mechanistic observations demonstrated that duloxetine is an attractive candidate to attenuate TRAIL resistance and provides an effective combination therapy regimen for lung cancer. This study lays the foundation for future experiments to select appropriate treatments for patients with cancer who are affected by depression.

\section{Conflicts of Interest}

The Authors declare no conflicts of interest regarding this study.

\section{Acknowledgements}

This study was supported by the National Research Foundation of the Korea Grant (NRF) funded by the Ministry of Education (2019R1A2B5B02069765). 


\section{Authors' Contributions}

K.M.A.Z. and S.Y.P. designed, executed the study, analyzed data and wrote the manuscript. All Authors have read and approved the final manuscript.

\section{References}

1 Seiwert TY, Connell PP, Mauer AM, Hoffman PC, George CM, Szeto L, Salgia R, Posther KE, Nguyen B, Haraf DJ and Vokes EE: A phase I study of pemetrexed, carboplatin, and concurrent radiotherapy in patients with locally advanced or metastatic nonsmall cell lung or esophageal cancer. Clin Cancer Res 13(2 Pt 1): 515-522, 2007. PMID: 17255273. DOI: 10.1158/1078-0432.Ccr06-1058

2 Jemal A, Bray F, Center MM, Ferlay J, Ward E and Forman D: Global cancer statistics. CA Cancer J Clin 61(2): 69-90, 2011 PMID: 21296855. DOI: 10.3322/caac. 20107

3 Ettinger DS, Akerley W, Borghaei H, Chang AC, Cheney RT, Chirieac LR, D’Amico TA, Demmy TL, Ganti AK, Govindan R, Grannis FW Jr., Horn L, Jahan TM, Jahanzeb M, Kessinger A, Komaki R, Kong FM, Kris MG, Krug LM, Lennes IT, Loo BW Jr., Martins R, O’Malley J, Osarogiagbon RU, Otterson GA, Patel JD, Pinder-Schenck MC, Pisters KM, Reckamp K, Riely GJ, Rohren E, Swanson SJ, Wood DE, Yang SC, Hughes M and Gregory KM: Non-small cell lung cancer. J Natl Compr Canc Netw 10(10): 1236-1271, 2012. PMID: 23054877. DOI: $10.6004 /$ jnccn.2012.0130

4 Heinzmann K, Nguyen QD, Honess D, Smith DM, Stribbling S, Brickute D, Barnes C, Griffiths J and Aboagye E: Depicting changes in tumor biology in response to cetuximab monotherapy or combination therapy by apoptosis and proliferation imaging using (18)f-icmt-11 and (18)f-flt pet. J Nucl Med 59(10): 15581565, 2018. PMID: 29794225. DOI: 10.2967/jnumed.118.209304

5 Zhang SH, Liu GF, Li XF, Liu L and Yu SN: Efficacy of different chemotherapy regimens in treatment of advanced or metastatic pancreatic cancer: A network meta-analysis. J Cell Physiol 233(4): 3352-3374, 2018. PMID: 28926090. DOI: 10.1002/ jcp. 26183

6 Rasheduzzaman M and Park SY: Antihypertensive drug-candesartan attenuates trail resistance in human lung cancer via ampkmediated inhibition of autophagy flux. Exp Cell Res 368(1): 126135, 2018. PMID: 29694835. DOI: 10.1016/j.yexcr.2018.04.022

7 Nowak-Sliwinska P, Scapozza L and Altaba ARI: Drug repurposing in oncology: Compounds, pathways, phenotypes and computational approaches for colorectal cancer. Biochim Biophys Acta Rev Cancer 1871(2): 434-454, 2019. PMID: 31034926. DOI: 10.1016/j.bbcan.2019.04.005

8 Jia Y, Yun CH, Park E, Ercan D, Manuia M, Juarez J, Xu C, Rhee K, Chen T, Zhang H, Palakurthi S, Jang J, Lelais G, DiDonato M, Bursulaya B, Michellys PY, Epple R, Marsilje TH, McNeill M, Lu W, Harris J, Bender S, Wong KK, Janne PA and Eck MJ: Overcoming egfr(t790m) and egfr(c797s) resistance with mutantselective allosteric inhibitors. Nature 534(7605): 129-132, 2016. PMID: 27251290. DOI: 10.1038/nature 17960

9 Aggarwal BB: Signalling pathways of the tnf superfamily: A double-edged sword. Nat Rev Immunol 3(9): 745-756, 2003. PMID: 12949498. DOI: $10.1038 /$ nri1184

10 Takeda K, Stagg J, Yagita H, Okumura K and Smyth MJ: Targeting death-inducing receptors in cancer therapy. Oncogene
26(25): 3745-3757, 2007. PMID: 17530027. DOI: 10.1038/ sj.onc. 1210374

11 Nazim UM, Rasheduzzaman M, Lee YJ, Seol DW and Park SY: Enhancement of trail-induced apoptosis by 5 -fluorouracil requires activating bax and p53 pathways in trail-resistant lung cancers. Oncotarget 8(11): 18095-18105, 2017. PMID: 28178647. DOI: 10.18632/oncotarget.14994

12 Aggarwal BB, Bhardwaj U and Takada Y: Regulation of trailinduced apoptosis by ectopic expression of antiapoptotic factors. Vitam Horm 67: 453-483, 2004. PMID: 15110190. DOI: 10.1016/s0083-6729(04)67023-3

13 Grotzer MA, Eggert A, Zuzak TJ, Janss AJ, Marwaha S, Wiewrodt BR, Ikegaki N, Brodeur GM and Phillips PC: Resistance to trailinduced apoptosis in primitive neuroectodermal brain tumor cells correlates with a loss of caspase-8 expression. Oncogene 19(40): 4604-4610, 2000. PMID: 11030149. DOI: 10.1038/sj.onc.1203816

14 Gasparini C, Vecchi Brumatti L, Monasta L and Zauli G: Trailbased therapeutic approaches for the treatment of pediatric malignancies. Curr Med Chem 20(17): 2254-2271, 2013. PMID: 23458616. DOI: $10.2174 / 0929867311320170009$

15 Chen SZ: [progress on targeting trail's receptor as antitumor strategy]. Yao Xue Xue Bao 44(12): 1336-1342, 2009. PMID: 21351465.

16 Kelley SK and Ashkenazi A: Targeting death receptors in cancer with apo21/trail. Curr Opin Pharmacol 4(4): 333-339, 2004. PMID: 15251125. DOI: 10.1016/j.coph.2004.02.006

17 Mongiat M, Ligresti G, Marastoni S, Lorenzon E, Doliana R and Colombatti A: Regulation of the extrinsic apoptotic pathway by the extracellular matrix glycoprotein emilin2. Mol Cell Biol 27(20): 7176-7187, 2007. PMID: 17698584. DOI: 10.1128/ mcb.00696-07

18 Wang S: Trail: A sword for killing tumors. Curr Med Chem 17(29): 3309-3317, 2010. PMID: 20712573. DOI: 10.2174/0929 86710793176285

19 Jin CY, Park C, Hwang HJ, Kim GY, Choi BT, Kim WJ and Choi YH: Naringenin up-regulates the expression of death receptor 5 and enhances trail-induced apoptosis in human lung cancer a549 cells. Mol Nutr Food Res 55(2): 300-309, 2011. PMID: 20669244. DOI: $10.1002 / \mathrm{mnfr} .201000024$

20 Cretney E, Takeda K and Smyth MJ: Cancer: Novel therapeutic strategies that exploit the tnf-related apoptosis-inducing ligand (trail)/trail receptor pathway. Int J Biochem Cell Biol 39(2): 280286, 2007. PMID: 17097329. DOI: 10.1016/j.biocel.2006.10.005

21 Manzo F, Nebbioso A, Miceli M, Conte M, De Bellis F, Carafa V, Franci G, Tambaro FP and Altucci L: Tnf-related apoptosis-inducing ligand: Signalling of a 'smart' molecule. Int J Biochem Cell Biol 41(3): 460-466, 2009. PMID: 18243765. DOI: 10.1016/j.biocel.2007.12.012

22 Dai X, Zhang J, Arfuso F, Chinnathambi A, Zayed ME, Alharbi SA, Kumar AP, Ahn KS and Sethi G: Targeting tnf-related apoptosis-inducing ligand (trail) receptor by natural products as a potential therapeutic approach for cancer therapy. Exp Biol Med (Maywood) 240(6): 760-773, 2015. PMID: 25854879. DOI: $10.1177 / 1535370215579167$

23 Ding J, Polier G, Kohler R, Giaisi M, Krammer PH and Li-Weber $\mathrm{M}$ : Wogonin and related natural flavones overcome tumor necrosis factor-related apoptosis-inducing ligand (trail) protein resistance of tumors by down-regulation of c-flip protein and up-regulation of trail receptor 2 expression. J Biol Chem 287(1): 641-649, 2012. PMID: 22086925. DOI: 10.1074/jbc.M111.286526 
24 Kuwahara J, Yamada T, Egashira N, Ueda M, Zukeyama N, Ushio $\mathrm{S}$ and Masuda S: Comparison of the anti-tumor effects of selective serotonin reuptake inhibitors as well as serotonin and norepinephrine reuptake inhibitors in human hepatocellular carcinoma cells Biol Pharm Bull 38(9): 1410-1414, 2015. PMID: 26328498. DOI: 10.1248/bpb.b15-00128

25 Meng J, Zhang Q, Yang C, Xiao L, Xue Z and Zhu J: Duloxetine, a balanced serotonin-norepinephrine reuptake inhibitor, improves painful chemotherapy-induced peripheral neuropathy by inhibiting activation of p38 mapk and nf-kappab. Front Pharmacol 10: 365, 2019. PMID: 31024320. DOI: 10.3389/fphar.2019.00365

26 Schmid D and Munz C: Innate and adaptive immunity through autophagy. Immunity 27(1): 11-21, 2007. PMID: 17663981. DOI: 10.1016/j.immuni.2007.07.004

27 Mizushima N: Physiological functions of autophagy. Curr Top Microbiol Immunol 335: 71-84, 2009. PMID: 19802560. DOI: 10.1007/978-3-642-00302-8_3

28 Mizushima N, Yoshimori T and Levine B: Methods in mammalian autophagy research. Cell 140(3): 313-326, 2010. PMID: 20144757. DOI: $10.1016 /$ j.cell.2010.01.028

29 Schmid D and Munz C: Immune surveillance via self digestion. Autophagy 3(2): 133-135, 2007. PMID: 17204851. DOI: 10.4161/auto.359130

30 Viry E, Paggetti J, Baginska J, Mgrditchian T, Berchem G, Moussay E and Janji B: Autophagy: An adaptive metabolic response to stress shaping the antitumor immunity. Biochem Pharmacol 92(1): 31-42, 2014. PMID: 25044308. DOI: 10.1016/j.bcp.2014.07.00631

31 Kondo Y, Kanzawa T, Sawaya R and Kondo S: The role of autophagy in cancer development and response to therapy. Nat Rev Cancer 5(9): 726-734, 2005. PMID: 16148885 . DOI: $10.1038 / \mathrm{nrc1692}$

32 Wu J, Dang Y, Su W, Liu C, Ma H, Shan Y, Pei Y, Wan B, Guo J and $\mathrm{Yu} \mathrm{L}$ : Molecular cloning and characterization of rat lc3a and $1 \mathrm{c} 3 \mathrm{~b}$ - two novel markers of autophagosome. Biochem Biophys Res Commun 339(1): 437-442, 2006. PMID: 16300744. DOI: 10.1016/j.bbrc.2005.10.211

33 Gomez-Sanchez R, Yakhine-Diop SM, Rodriguez-Arribas M, Bravo-San Pedro JM, Martinez-Chacon G, Uribe-Carretero E, Pinheiro de Castro DC, Pizarro-Estrella E, Fuentes JM and Gonzalez-Polo RA: Mrna and protein dataset of autophagy markers (lc3 and p62) in several cell lines. Data Brief 7: 641-647, 2016. PMID: 27054171. DOI: 10.1016/j.dib.2016.02.085

34 Tanida I and Waguri S: Measurement of autophagy in cells and tissues. Methods Mol Biol 648: 193-214, 2010. PMID: 20700714. DOI: $10.1007 / 978-1-60761-756-3 \_13$

35 Apel A, Herr I, Schwarz H, Rodemann HP and Mayer A: Blocked autophagy sensitizes resistant carcinoma cells to radiation therapy. Cancer Res 68(5): 1485-1494, 2008. PMID: 18316613. DOI: 10.1158/0008-5472.CAN-07-0562

36 Boya P, Gonzalez-Polo RA, Casares N, Perfettini JL, Dessen P, Larochette N, Metivier D, Meley D, Souquere S, Yoshimori T, Pierron G, Codogno P and Kroemer G: Inhibition of macroautophagy triggers apoptosis. Mol Cell Biol 25(3): 1025-1040, 2005. PMID: 15657430. DOI: 10.1128/mcb.25.3.1025-1040.2005

37 Carew JS, Medina EC, Esquivel JA, 2nd, Mahalingam D, Swords R, Kelly K, Zhang H, Huang P, Mita AC, Mita MM, Giles FJ and Nawrocki ST: Autophagy inhibition enhances vorinostat-induced apoptosis via ubiquitinated protein accumulation. J Cell Mol Med 14(10): 2448-2459, 2010. PMID: 19583815. DOI: 10.1111/j.1582-4934.2009.00832.x
38 Pan H, Wang Y, Na K, Wang Y, Wang L, Li Z, Guo C, Guo D and Wang $\mathrm{X}$ : Autophagic flux disruption contributes to ganoderma lucidum polysaccharide-induced apoptosis in human colorectal cancer cells via mapk/erk activation. Cell Death Dis 10(6): 456, 2019. PMID: 31186406. DOI: 10.1038/s41419-019-1653-7

39 Hwang KE, Kim YS, Jung JW, Kwon SJ, Park DS, Cha BK, Oh $\mathrm{SH}$, Yoon KH, Jeong ET and Kim HR: Inhibition of autophagy potentiates pemetrexed and simvastatin-induced apoptotic cell death in malignant mesothelioma and non-small cell lung cancer cells. Oncotarget 6(30): 29482-29496, 2015. PMID: 26334320. DOI: $10.18632 /$ oncotarget.5022

40 Schmid D, Pypaert M and Munz C: Antigen-loading compartments for major histocompatibility complex class ii molecules continuously receive input from autophagosomes. Immunity 26(1): 79-92, 2007. PMID: 17182262. DOI: 10.1016/j.immuni.2006.10.018

41 Heckmann BL, Yang X, Zhang X and Liu J: The autophagic inhibitor 3-methyladenine potently stimulates pka-dependent lipolysis in adipocytes. Br J Pharmacol 168(1): 163-171, 2013. PMID: 22817685. DOI: 10.1111/j.1476-5381.2012.02110.x

42 Zou Y, Chen M, Zhang S, Miao Z, Wang J, Lu X and Zhao X: Trpc5induced autophagy promotes the tmzresistance of glioma cells via the cammkbeta/ampkalpha/mtor pathway. Oncol Rep 41(6): 3413-3423, 2019. PMID: 30942446. DOI: 10.3892/or.2019.7095

43 Chen L, Xu B, Liu L, Luo Y, Zhou H, Chen W, Shen T, Han X, Kontos CD and Huang S: Cadmium induction of reactive oxygen species activates the mtor pathway, leading to neuronal cell death. Free Radic Biol Med 50(5): 624-632, 2011. PMID: 21195169. DOI: $10.1016 /$ j.freeradbiomed.2010.12.032

44 Wang N, He J, Pan C, Wang J, Ma M, Shi X and Xu Z: Resveratrol activates autophagy via the akt/mtor signaling pathway to improve cognitive dysfunction in rats with chronic cerebral hypoperfusion. Front Neurosci 13: 859, 2019. PMID: 31481868. DOI: $10.3389 /$ fnins.2019.00859

45 Di Rosso ME, Sterle HA, Cremaschi GA and Genaro AM: Beneficial effect of fluoxetine and sertraline on chronic stressinduced tumor growth and cell dissemination in a mouse model of lymphoma: Crucial role of antitumor immunity. Front Immunol 9: 1341, 2018. PMID: 29971064. DOI: 10.3389/fimmu.2018.01341

46 Thaker PH, Han LY, Kamat AA, Arevalo JM, Takahashi R, Lu C, Jennings NB, Armaiz-Pena G, Bankson JA, Ravoori M, Merritt WM, Lin YG, Mangala LS, Kim TJ, Coleman RL, Landen CN, Li Y, Felix E, Sanguino AM, Newman RA, Lloyd M, Gershenson DM, Kundra V, Lopez-Berestein G, Lutgendorf SK, Cole SW and Sood AK: Chronic stress promotes tumor growth and angiogenesis in a mouse model of ovarian carcinoma. Nat Med 12(8): 939944, 2006. PMID: 16862152. DOI: $10.1038 / \mathrm{nm} 1447$

47 Kim-Fuchs C, Le CP, Pimentel MA, Shackleford D, Ferrari D, Angst E, Hollande F and Sloan EK: Chronic stress accelerates pancreatic cancer growth and invasion: A critical role for betaadrenergic signaling in the pancreatic microenvironment. Brain Behav Immun 40: 40-47, 2014. PMID: 24650449. DOI: 10.1016/j.bbi.2014.02.019

48 Hassan S, Karpova Y, Baiz D, Yancey D, Pullikuth A, Flores A, Register T, Cline JM, D’Agostino R Jr., Danial N, Datta SR and Kulik G: Behavioral stress accelerates prostate cancer development in mice. J Clin Invest 123(2): 874-886, 2013. PMID: 23348742. DOI: 10.1172/jci63324

49 Sloan EK, Priceman SJ, Cox BF, Yu S, Pimentel MA, Tangkanangnukul V, Arevalo JM, Morizono K, Karanikolas BD, 
Wu L, Sood AK and Cole SW: The sympathetic nervous system induces a metastatic switch in primary breast cancer. Cancer Res 70(18): 7042-7052, 2010. PMID: 20823155. DOI: 10.1158/00085472.Can-10-0522

50 Hasegawa $\mathrm{H}$ and Saiki I: Psychosocial stress augments tumor development through beta-adrenergic activation in mice. Jpn J Cancer Res 93(7): 729-735, 2002. PMID: 12149137. DOI: 10.1111/j.1349-7006.2002.tb01313.x

51 Moura ECR, da Cunha Leal P, Serra I, de Paulo Ribeiro B, do Nascimento JR, do Nascimento FRF and Sakata RK: Tumor growth activity of duloxetine in ehrlich carcinoma in mice. BMC Res Notes 11(1): 525, 2018. PMID: 30064486. DOI: 10.1186/s 13104-018-3655-4

52 Shankar S and Srivastava RK: Enhancement of therapeutic potential of trail by cancer chemotherapy and irradiation: Mechanisms and clinical implications. Drug Resist Updat 7(2): 139-156, 2004. PMID: 15158769. DOI: 10.1016/j.drup.2004.03.002

53 Van Geelen CM, de Vries EG and de Jong S: Lessons from trailresistance mechanisms in colorectal cancer cells: Paving the road to patient-tailored therapy. Drug Resist Updat 7(6): 345-358, 2004. PMID: 15790545. DOI: 10.1016/j.drup.2004.11.002

54 Meurette O, Fontaine A, Rebillard A, Le Moigne G, Lamy T, Lagadic-Gossmann D and Dimanche-Boitrel MT: Cytotoxicity of trail/anticancer drug combinations in human normal cells. Ann N Y Acad Sci 1090: 209-216, 2006. PMID: 17384264. DOI: 10.1196/annals.1378.023

55 Wang S: The promise of cancer therapeutics targeting the tnfrelated apoptosis-inducing ligand and trail receptor pathway. Oncogene 27(48): 6207-6215, 2008. PMID: 18931688. DOI: $10.1038 /$ onc 2008.298

56 Harper N, Hughes M, MacFarlane M and Cohen GM: Fas-associated death domain protein and caspase- 8 are not recruited to the tumor necrosis factor receptor 1 signaling complex during tumor necrosis factor-induced apoptosis. J Biol Chem 278(28): 25534 25541, 2003. PMID: 12721308. DOI: 10.1074/jbc.M303399200

57 Walczak H, Miller RE, Ariail K, Gliniak B, Griffith TS, Kubin M, Chin W, Jones J, Woodward A, Le T, Smith C, Smolak P, Goodwin RG, Rauch CT, Schuh JC and Lynch DH: Tumoricidal activity of tumor necrosis factor-related apoptosis-inducing ligand in vivo. Nat Med 5(2): 157-163, 1999. PMID: 9930862. DOI: 10.1038/5517

$58 \mathrm{Wu}$ GS: Trail as a target in anti-cancer therapy. Cancer Lett 285(1): 1-5, 2009. PMID: 19299078. DOI: 10.1016/j.canlet.2009.02.029

59 Anding AL and Baehrecke EH: Cleaning house: Selective autophagy of organelles. Dev Cell 41(1): 10-22, 2017. PMID: 28399394. DOI: 10.1016/j.devcel.2017.02.016
60 Li CF, Pan YK, Gao Y, Shi F, Wang YC and Sun XQ: Autophagy protects huvecs against er stress-mediated apoptosis under simulated microgravity. Apoptosis 24(9-10): 812-825, 2019. PMID: 31359205. DOI: 10.1007/s10495-019-01560-w

61 Park EJ, Min KJ, Choi KS, Kubatka P, Kruzliak P, Kim DE and Kwon TK: Chloroquine enhances trail-mediated apoptosis through up-regulation of $\mathrm{dr} 5$ by stabilization of mrna and protein in cancer cells. Sci Rep 6: 22921, 2016. PMID: 26964637. DOI: 10.1038/srep22921

62 Thorburn A: Apoptosis and autophagy: Regulatory connections between two supposedly different processes. Apoptosis 13(1): 19, 2008. PMID: 17990121. DOI: 10.1007/s 10495-007-0154-9

63 Bagamanshina AV, Troitskaya OS, Nushtaeva AA, Yunusova AY, Starykovych MO, Kuligina EV, Kit YY, Richter M, Wohlfromm F, Kahne T, Lavrik IN, Richter VA and Koval OA: Cytotoxic and antitumor activity of lactaptin in combination with autophagy inducers and inhibitors. Biomed Res Int 2019: 4087160, 2019. PMID: 31317028. DOI: 10.1155/2019/4087160

64 Liu X, Chhipa RR, Nakano I and Dasgupta B: The ampk inhibitor compound $\mathrm{c}$ is a potent ampk-independent antiglioma agent. Mol Cancer Ther 13(3): 596-605, 2014. PMID: 24419061. DOI: 10.1158/1535-7163.Mct-13-0579

65 Harhaji-Trajkovic L, Vilimanovich U, Kravic-Stevovic T, Bumbasirevic V and Trajkovic V: Ampk-mediated autophagy inhibits apoptosis in cisplatin-treated tumour cells. J Cell Mol Med 13(9b): 3644-3654, 2009. PMID: 20196784. DOI: 10.1111/j.1582-4934.2009.00663.x

$66 \mathrm{Hu}$ X, Shi S, Wang H, Yu X, Wang Q, Jiang S, Ju D, Ye L and Feng M: Blocking autophagy improves the anti-tumor activity of afatinib in lung adenocarcinoma with activating egfr mutations in vitro and in vivo. Sci Rep 7(1): 4559, 2017. PMID: 28676644. DOI: $10.1038 / \mathrm{s} 41598-017-04258-8$

67 Mauthe M, Orhon I, Rocchi C, Zhou X, Luhr M, Hijlkema KJ, Coppes RP, Engedal N, Mari M and Reggiori F: Chloroquine inhibits autophagic flux by decreasing autophagosome-lysosome fusion. Autophagy 14(8): 1435-1455, 2018. PMID: 29940786. DOI: $10.1080 / 15548627.2018 .1474314$
Received September 24, 2019

Revised October 30, 2019

Accepted October 31, 2019 